\title{
The contribution of the maternal immune system to the establishment of pregnancy in cattle
}

\author{
Trudee Fair * \\ School of Agriculture and Food Sciences, University College Dublin, Dublin, Ireland
}

Edited by:

Kieran G. Meade, Teagasc, Ireland

Reviewed by:

Annapurna Nayak, Brunel University,

UK

Peter James Hansen, University of

Florida, USA

Robert Owen Gilbert, Cornell

University, USA

*Correspondence:

Trudee Fair, School of Agriculture and

Food Sciences, University College

Dublin, Room 239, Agricultural

Sciences Building, Belfield, Dublin 4, Ireland

e-mail: trudee.fair@ucd.ie
Immune cells play an integral role in affecting successful reproductive function. Indeed, disturbed or aberrant immune function has been identified as primary mechanisms behind infertility. In contrast to the extensive body of literature that exists for human and mouse, studies detailing the immunological interaction between the embryo and the maternal endometrium are quite few in cattle. Nevertheless, by reviewing the existing studies and extrapolating from sheep, pig, mouse, and human data, we can draw a reasonably comprehensive picture. Key contributions of immune cell populations include granulocyte involvement in follicle differentiation and gamete transfer, monocyte invasion of the periovulatory follicle and their subsequent role in corpus luteum formation and the pivotal roles of maternal macrophage and dendritic cells in key steps of the establishment of pregnancy, particularly, the maternal immune response to the embryo. These contributions are reviewed in detail below and key findings are discussed.

Keywords: cow, fertility, macrophage, cytokine, immune function

\section{BACKGROUND}

It is estimated that fetal viability is only achieved in about $55 \%$ of fertilizations in non-compromised cattle, indicating an embryonic/fetal mortality of about $35 \%$. It is estimated that 70 $80 \%$ of the total embryonic loss occurs between days 8 and 16 after insemination [day 16 corresponding to the day of maternal recognition of pregnancy; reviewed by Diskin and Morris (1)]. There are many reasons, related to both the mother and the embryo, why implantation fails but there is increasing interest in the role of the maternal immune system. Disturbed or aberrant immune function has been identified as primary mechanisms behind infertility. In contrast to the extensive body of literature that exists for human and mouse, studies detailing the immunological interaction between the embryo and the maternal endometrium in cattle have primarily focused on the role of the maternal recognition factor, the type I antiviral cytokine, interferon tau $(2,3)$ in corpus luteum (CL) maintenance, and progesterone priming of the endometrium. Nevertheless, by reviewing the existing studies and extrapolating from sheep, pig, mouse, and human data, we can draw a reasonably comprehensive picture of immune cell involvement from follicle development, ovulation, gamete transfer, maternal recognition of pregnancy, implantation, and placentation. These events are reviewed below and key findings are discussed.

\section{OVARIAN FUNCTION}

The presence and temporal regulation of neutrophils, eosinophils, macrophages $(\mathrm{M} \Phi)$, granulocytes, and T-lymphocytes in ovarian tissues has been characterized extensively during the menstrual cycle in women; a smaller body of data exists for several farm animal species, including cows, sheep, pigs, buffaloes, and horses (4).

\section{FOLLICLE DIFFERENTIATION}

Taken together, pre-ovulatory follicle differentiation and luteinization appear to be characterized by three phases of immune cell infiltration, which are illustrated in Figure 1: histological analysis of bovine dominant follicles shows that mast cell infiltration of the theca layer constitutes the first phase (5) (Figure 1A), luteinizing hormone (LH) triggered degranulation of the mast cells stimulates the second phase through the direct and indirect actions of TNF-alpha (TNFA), a constituent of the granules (Figure 1B). The second phase has been characterized in sheep and pigs as an influx of eosinophilic and neutrophilic granulocytes and Tlymphocytes $(6,7)$. The last phase of leukocyte migration consists of phagocytic monocytes (Mo); MФ's increase in the sow and ewe follicles at the time of ovulation $(6,7)$ (Figure 1C), possibly in response to peak estradiol concentrations (8). The temporal changes in the influx of leukocytes appear to occur in response to various chemoattractant cues produced by the developing follicle (9), indeed leukocyte chemoattractant activity has been demonstrated in bovine, ovine, and human follicular fluid of ovulatory follicles (10-12). Immunohistochemical characterization of the immune cell repertoire of the bovine ovary has largely focused on the formation and regression of the CL, which will be discussed later. In contrast, there are many reports detailing the transcriptomic profile of ovarian follicle development in cattle: (13-19). In particular, the deep sequencing analysis of bovine follicular theca and granulosa tissue during pre-ovulatory follicle development, revealed a profound effect of ovarian follicle stage on the expression of many genes within immune-related pathways in these tissues: during follicle differentiation, bovine thecal tissue was characterized by the expression of immune factors associated with vascularization, angiogenesis, and cellular proliferation $(15,20)$, processes which are carried out by $M \Phi$ 's in the theca layer during this time $(21,22)$. The bovine transcriptomic data 


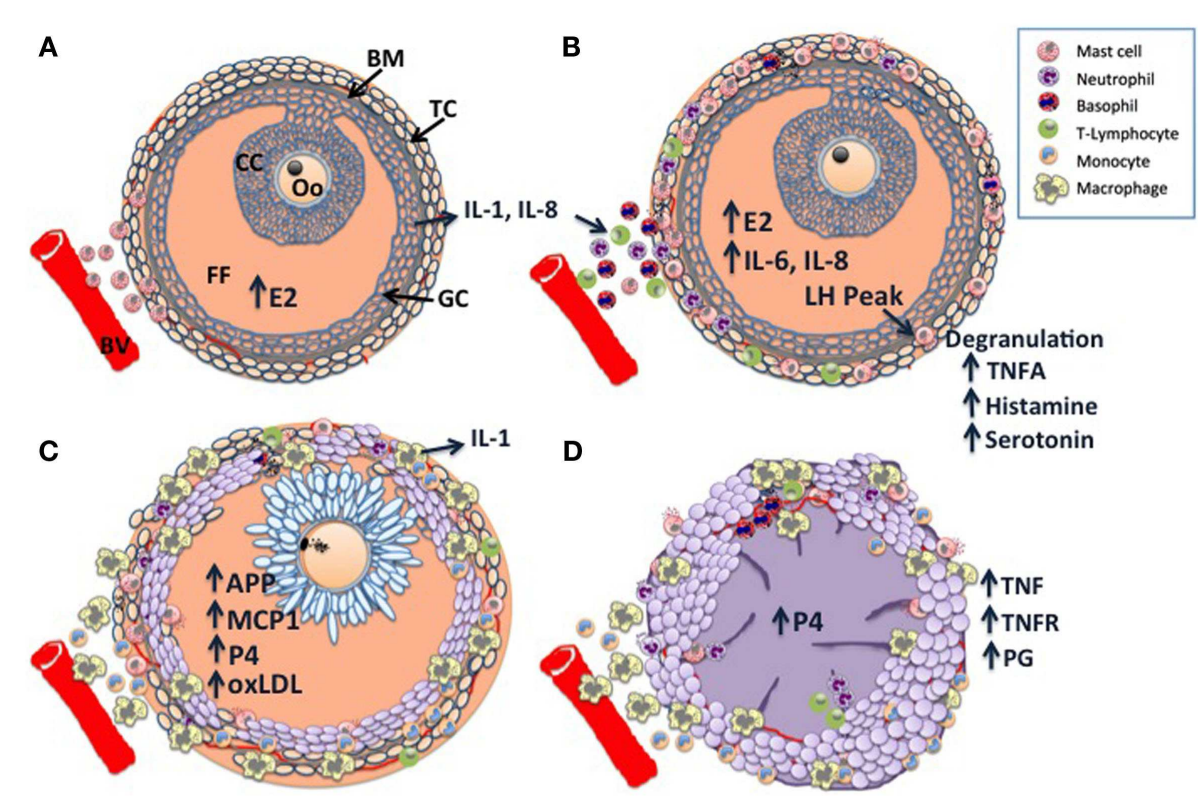

FIGURE 1 | Schematic diagram of dominant follicle differentiation and corpus luteum formation: follicle differentiation and luteinization appear to be characterized by three waves of immune cell infiltration. (A) Mast cell infiltration of the thecal cell layer (TC) triggered by increasing estradiol (E2) concentrations, note the intact basement membrane (BM) separating the follicle granulosa-cell layer (GC) and follicle contents [cumulus cell layer $(\mathrm{CC})$, surrounding the oocyte $(\mathrm{OO})$, and the follicular fluid FF] from the ovarian stroma. (B) A peak in luteinizing hormone (LH) pulsatility triggers mast cell degranulation which stimulates the second wave through the direct and indirect actions of TNF-alpha (TNFA), a constituent of the granules. (C) The last wave is characterized by macrophage infiltration, possibly in response to E2 and other chemoattractants such as monocyte chemoattractant protein 1 (MCP1), acute phase proteins (APP), and GC derived oxidized low density lipoprotein (oxLDL). Note the expanded cumulus cells surrounding the metaphase II stage oocyte, there is a switch from E2 synthesis to progesterone synthesis as the follicular cells become luteinized. (D) Following ovulation, granulocytes, neutrophils, and eosinophils constitute the majority of immune cells within the developing corpus luteum $(C L)$, with further infiltration of macrophages and endothelial cells as development and vascularization proceed. Macrophage derived tumor necrosis factor (TNF) is a potent stimulator of luteal prostaglandins (PG), including PGF2a, PGE2, and PG112, which in concert with TNF drive $C L$ vascularization. Large luteal cells derived primarily from the granulosa cells produce the $>80 \%$ of $\mathrm{P} 4$. also concurred with the histological findings described for sheep and pigs, as factors with known inflammatory/chemotactic properties such as AKT2, ARHGEF1, GNAI2, IL-1, IL-6, and $I L-8 b$ (23-25) were upregulated and pathways associated with $M \Phi$ and neutrophil function were overpopulated in differentiating thecal tissue (15).

\section{FOLLICLE LUTEINIZATION AND OVULATION}

Findings from studies using rodent models indicate that the initiation of the ovulatory process occurs primarily in granulosa cells (26). Following the pre-ovulatory LH surge, morphological, endocrinological, and biochemical changes occur in the theca and granulosa cells, which redirect pre-ovulatory follicle development from differentiation to luteinization and thus the early stages of CL development (26). In particular, the post-LH deterioration of the basement membrane (BM) between the theca and granulosa-cell layers (GCs) (27), facilitates the movement of leukocytes into the granulosa tissue at luteinization, reflected by the peri-ovulatory granulosa-cell expression of factors involved in acute inflammation and immunosurveillance $(15,26,28)$. It has been hypothesized that the dramatic increase in the expression of these signals in the follicle compartment activates the ovarian innate immune system (29) and that the damaged granulosa cells actively secrete alarmins or passively release them after death (30). Alarmins include acute phase proteins (APP), S100 proteins, advanced glycation endproducts (AGE), high mobility group box-1 protein (HMGB1), defensins, and interleukin (IL)-1 $\alpha$, which are all present in follicle cells and the follicular fluid of pre-ovulatory follicles $(26,31-34)$ and can engage toll-like receptors (TLRs). In the case of ovarian granulosa cells, oxidized low density lipoprotein (oxLDL), which engages with TLR4 (34), has been proposed as a key alarmin in the pre-ovulatory cascade (29). This hypothesis is further supported by the identification of granulosa-cell exclusive expression of TLR signaling and NF- $\mathrm{KB}$ signaling pathways during luteinization in the bovine transcriptomic data (15). Furthermore, comparing the gene expression profiles of follicular tissue from heifers to that of lactating cows, it would appear that the recruitment of leukocytes to the differentiating follicle is delayed in cows. This is possibly a result of the demands of parturition/lactation in dairy cows, resulting in a reduced positive feedback loop, whereby lower steroid levels and chemoattractant signals recruit fewer leukocytes into the follicle, leading to lower steroid and chemoattractant levels (15).

\section{CORPUS LUTEUM FORMATION}

The CL is a transient organ established by cells of the follicle following ovulation; it is composed of a heterogeneous mixture of cell types that consist of not only steroidogenic luteal cells but also non-steroidogenic cells including vascular endothelial cells, 
fibroblasts, and immune cells such as lymphocytes and $M \Phi$ 's (35). Studies in human, rat and sheep indicate that the immune cells of the developing CL are recruited during ovulation (3639) (Figure 1D), they were determined to have originated from the spleen (38), see Ref. (40), for review. Histological data from cattle indicate that they are primarily granulocytes, neutrophils, and eosinophils $(35,41,42)$. However, as CL development and vascularization progresses, $M \Phi$ 's and endothelial cells infiltrate (43), providing a source of TNF and TNFR, the presence of which have been demonstrated in the bovine CL (44). TNF is a potent stimulator of luteal prostaglandins (PG) including PGF2a, PGE2, and PG12 (45), TNF and TNF-induced PGE2 have been proposed as key regulators of CL vascularization (46), recent work in the mare supports this hypothesis (47). Exposure to seminal plasma has been shown to enhance CL development and ovarian steroidogenesis: gilts treated with seminal plasma had heavier CLs, higher plasma progesterone (P4) levels, which peaked earlier, without a concurrent increase in ovulation rate, suggesting that the number and output of steroidogenic luteal cells is greater in animals exposed to seminal components (48). Immunohistochemical analysis revealed a greater abundance of predominantly major histocompatibility complex (MHC) class II positive $M \Phi$ 's and/or DCs in the stromal tissues and thecal cells of pre- and periovulatory follicles, implying greater leukocyte recruitment at the time of ovulation in seminal plasma treated animals (49).

Immune function is central to CL regression, which must occur in the absence of pregnancy in order for new follicular development to take place (40). The regressing $C L$ is characterized by an increase in $M \Phi$ and Mo populations, which eventually constitute the major proliferating cell type of the late regressing CL (40). The number of T-lymphocytes appears to increase just prior to the onset of luteolysis $(35,50)$, analysis of the bovine CL T-lymphocyte population revealed that $25 \%$ of T-lymphocytes present in a functional CL were $\mathrm{T}$ helper cells $\left(\mathrm{CD}^{+}\right), 45 \%$ were cytotoxic T-cells $\left(\mathrm{CD}^{+}\right)$, and $30 \%$ were gamma delta $\left(\gamma \delta^{+}\right)$T-cells and that this profile did not alter during luteolysis (51). However, decreased P4 levels and interruption of growth factor signaling in the $\mathrm{CL}$ appear to promote both $\mathrm{M} \Phi$ and T-cell activation, leading to increased TNF and INF production, respectively (52-55). TNF and INF are likely to be key regulators of apoptosis and ovarian tissue remodeling (56), their receptors are expressed in bovine steroidogenic cells and luteal cells (57). It is probable that Fas expression is induced in luteal cells by leukocyte-derived cytokines and that Fas L expressed on T-lymphocytes transduces apoptotic signals to the luteal cells [see Ref. (46), for review]. This is likely to be a conserved action as both Fas and Fas $\mathrm{L}$ are expressed in theca cells in multiple species (58).

\section{GAMETE TRANSFER}

\section{INFLAMMATORY RESPONSE TO INSEMINATION}

The site of semen deposition is very much a species-specific location (59). In cattle, and also in humans, sperm enters the cervix canal rapidly after semen deposition. The stimulation of vaginal insemination ensures the migration of neutrophils in to the cervical and uterine tissues $(60,61)$ and has been proposed as the initial point to optimize pregnancy success (62). The early immune response to insemination appears to contribute to both the ovulatory process and sperm cell selection; as reports from several species, including cattle, suggest that neutrophilic granulocytes target dead or capacitated sperm, thus removing non-motile or damaged spermatozoa (63-65), rather than motile, fertile sperm (62). In both humans and mice, it has been clearly demonstrated that the post-mating inflammatory response is mainly caused by the seminal plasma, with sperm having a negligible part (66). The cytokine, transforming growth factor- $\beta$ (TGF $\beta$ ), is the principal inflammatory trigger found in seminal plasma; it is primarily present within the male seminal plasma fluid in latent form, which is activated in the female reproductive tract by plasmin and other enzymes after insemination $(62,67)$. Although TGF $\beta$ itself can be chemotactic for a variety of immune cell types (68), in the murine uterus it was reported to act indirectly, by inducing cytokine and chemokine expression (69).

\section{SPERM TRANSPORT}

The delivery of seminal fluid to the female reproductive tract at coitus represents the first exposure of the female immune system to paternal alloantigens (62), raising the possibility that the female activates an immune response to male antigens in seminal fluid that may ultimately confer immunological tolerance to paternal antigens (70). This theory is supported by data from mice, which show that chemoattractants, secreted by eosinophils and neutrophils, attract both Mos and DC's and shape the inflammatory status of MФ's $(71,72)$. The response is not restricted to vaginal exposure; intrauterine horn insemination was shown to induce recruitment of MHC class II positive cells in gilts (73). Seminal plasma contains estrogen and testosterone, $\mathrm{PG}$, and various signaling molecules, including IL-8, TGF $\beta$, and IFNG, as well as bacterial lipopolysaccharide (LPS) (62). When murine uterine and cervical cells come into contact with the constituents of semen, they are stimulated to synthesize and release granulocytemacrophage colony-stimulating factor (GM-CSF), IL-6, and further chemokines $(66,74)$, which stimulate $M \Phi$ 's, DC, and granulocyte infiltration of the uterine and cervical tissues (75). The induction of IL- 6 is required for TGF $\beta$ to induce the generation of IL-17 producing, pro-inflammatory TH-17 cells, which in turn favor the induction of neutrophil-chemotactic IL-8 (76). In conjunction with IL-8, TGF $\beta$ induces the secretion of pro-inflammatory cytokines such as IL-1B, IL-6, and leukemia inhibitory factor (LIF) (77). Although, the expression of TGF $\beta$ was shown to increase in the bovine endometrium during the implantation period (78), the relatively high pregnancy rates achieved in cattle following artificial insemination or embryo transfer undermines the importance of maternal exposure to seminal plasma in cattle. The findings of studies designed to address this point indicate that neither exposure to seminal plasma nor TGF $\beta$ is critical for to the establishment of pregnancy in cattle $(79,80)$.

\section{IMMUNE TOLERANCE POST-FERTILIZATION}

Exposure to paternal antigens occurs in two waves in the reproductive process: initially during transmission of seminal fluid at coitus, and secondly when placental trophoblast cells come in contact with maternal tissues during embryo implantation (81). In sheep and cattle, morula-stage embryos enter the uterus around day $4-5$ and blastocysts are formed by day 6 and 7, respectively, 
hatching occurs within $48-72 \mathrm{~h}$. The hatched blastocyst subsequently elongates reaching $10 \mathrm{~cm}$ or more in length by day 14 and $25 \mathrm{~cm}$ or more in length by day 17 and the conceptus trophectoderm and endometrial luminal epithelium (LE) become closely apposed, see Ref. (82), for review. Implantation is a superficial, protracted affair in these species, commencing after attachment and adhesion of the trophectoderm to caruncular and intercaruncular areas on day 16 in sheep and day 19 in cattle. Again, in contrast to the volume of data that has been acquired in human and mouse studies, the number of investigations carried out in farm animal species on the involvement of the maternal immune system in the establishment of pregnancy is very limited, particularly, for early pregnancy. For several decades, human pregnancy was described as a Th1/Th2 dichotomy with an imbalance toward a Th2 type immune response $(83,84)$. However, this paradigm is considered a simplistic explanation of the molecular events occurring during pregnancy, as it does not account for reported endometrial expression of Th1-type cytokines during implantation $(85,86)$. In ruminants, studies investigating maternal immunomodulation by pregnancy have focused on the actions of the type 1 interferon, IFNT, which is secreted by the elongating conceptus and is the main signaling factor in maternal detection/recognition of pregnancy $(87,88)$. Initial studies demonstrated that endometrial luminal epithelial cell estrogen receptor and oxytocin receptor expression was down regulated in response to IFNT $(89,90)$. Critically for the continuation of pregnancy in cattle, this binding eventually results in the attenuation of endometrial PGF2a secretion, allowing CL production of P4 to be maintained (90). In addition to its anti-luteolytic properties, IFNT appears to be the key regulator of the maternal immune response in ruminants $(91,92)$, acting on the endometrium to induce or enhance the expression of genes hypothesized to regulate uterine receptivity to implantation and conceptus development (78, 93-95). The expression of IFNT is limited to the embryonic trophectoderm during the peri-implantation period (96). Additionally, there is significant evidence that the bovine conceptus does not endeavor to conceal itself immunologically, as MHC-I transcripts have been detected in early cleavage stage bovine embryos (97) and in first and second trimester and term trophoblast tissues (98). Furthermore, $M H C$ class I mRNA expression by bovine embryos is both transcriptand embryo stage-specific (97) and can be regulated by a number of cytokines including IFNG, IL-4, and LIF $(99,100)$.

\section{MATERNAL RECOGNITION AND RESPONSE TO PREGNANCY MONOCYTES, MACROPHAGES, AND DENDRITIC CELLS}

Macrophage recruitment to the pregnant endometrium occurs in a wide range of mammalian species, including the mouse (101), human $(102,103)$, cynomolgus and vervet monkeys (104), sheep (105), and cattle $(78,106,107)$. While their role has not been completely elucidated, functions include clearing of apoptotic cells, regulation of apoptosis (108), and regulation of placental lactogen concentrations at the fetal-maternal interface (109). Given the potential antigenicity of the conceptus due to paternal antigen and classical MHC protein expression (97), MФ's may also feature in curtailing the activation of anti-conceptus immune responses (106). In cattle, the maternal immune response to the developing embryo is characterized by the expansion of Mo, MФ's
$\left(\mathrm{CD} 14^{+}\right.$-cells), and DC (CD172a-CD11c $\left.{ }^{+}\right)$populations in the endometrial stroma as early as day 13 of pregnancy (78). Interestingly, there was a parallel decrease in CD11 ${ }^{+}$-cells; CD11b is associated with Mo movement through the endothelium, which would imply that the Mo had acquired a stationary phenotype (78).

Dendritic cells have been shown to play an important role in decidua formation and the induction of immune tolerance in human and murine pregnancy $(110,111)$. Employing individual and combined CD172a and CD11c labeling of the bovine endometrium, it was determined that there was a high prevalence of immature cells within the endometrial DC population during early pregnancy (78). Immature DC's have been associated with the initiation and maintenance of peripheral tolerance (112) and their presence in large numbers in the uterine decidua has been associated with the establishment of healthy pregnancies in women (113). It is most likely that in cattle, IFNT induces this initial maternal response to the presence of the elongating embryo, either by attracting monocytes into endometrium or by modulating their differentiation into $M \Phi$ 's or DC. Indeed, gene expression analysis of the same endometrial tissue revealed dramatic up-regulation of mRNA expression of IFN stimulated genes $I L 12 B, M C P 1, M C P 2$, PTX3, RSAD2, ISG15, and TNFA (78). Furthermore, MCP1 and MCP2 are members of the cellular chemoattractant chemokine $\beta$ subfamily, which have highly potent $M \Phi$ recruitment and activation properties (114), thus increased $M C P 1$ and $M C P 2$ expression may be associated with the recruitment of $\mathrm{Mo} / \mathrm{M} \Phi$ from the systemic system into the endometrium. The up-regulation of the evolutionary conserved PTX3 is very interesting; gene deletion studies in mice have shown that it is essential for female fertility, participating in the assembly of the cumulus oophorus extra-cellular matrix (115). Moreover, PTX3 is involved in innate immunity, proposed roles include selected pathogen recognition, opsonization leading to enhanced phagocytosis, regulation of the inflammatory response, complement-mediated clearance of apoptotic cells, and control of autoimmunity (116-118).

\section{T-LYMPHOCYTES}

Despite the evidence from studies in humans and mice linking successful pregnancy with an imbalance toward a Th2 immune response type, data from cattle indicate that $\mathrm{CD}^{+}, \mathrm{CD}^{+}$, $\gamma \delta \mathrm{TCR}^{+}$, and FoxP3 T-lymphocyte populations are not regulated temporally during estrus or early pregnancy in cattle (119). However, mRNA expression analysis on the same tissue revealed that the Th1 immune factors IFNA, LIF, IL1B, IL8, and IL12A were down regulated during the luteal phase of the estrus cycle, whereas the Th2 factors LIF and IL10 were upregulated, suggesting that the phenotypes/inflammatory status of Th cells are tightly modulated during the estrous cycle in anticipation of pregnancy. Additionally, LIF and IL-10 have been shown to regulate M $\Phi$ activation $(120,121)$. Similarly, endometrial TGF $\beta 2$ expression is down regulated during the ovine and bovine implantation period and is subsequently increased during placentation $(78,122)$, which may reflect TGF $\beta 2$ involvement in Mo recruitment and regulation of $M \Phi$ inflammatory status (123). Furthermore, the study in cattle showed TGF $\beta$ localization to the fetal-maternal interface of the bovine placentome, which may indicate TGF $\beta 2$ involvement in restricting trophoblast invasion 
during the implantation phase, while enhanced expression during placentation and in vitro cell culture studies, suggest that TGF $\beta 2$ may play a mitogenic role during placentation, promoting caruncular growth, and coordinating epithelial cell development leading to placentome formation $(123,124)$.

Surprisingly, and in contrast to the situation in human and mouse models, where NK cells can constitute up to $70 \%$ of the endometrial lymphocyte population during the preimplantation phase of pregnancy (112), when uterine NK (UNK) cells are believed to play a pivotal role in local vascular remodeling and regulation of trophoblast invasion [for review see Ref. $(125,126)$ ]; NK cells do not appear to play such a critical role during early pregnancy in cattle. Indeed, the only published data suggests the bovine endometrium population of $\mathrm{CD} 335^{+} \mathrm{NK}$ cell population is not expanded as an immediate response to maternal recognition of pregnancy (119). The findings of an in vitro study which demonstrated anti-proliferative effects of recombinant IFNT exposure on immune and uterine cells, particularly leukocytes, infers that the IFNT secretion by the embryo may actively restrict NK cell expansion in early pregnancy (127), which is in keeping with the non-invasive nature of implantation in cattle [see review by Bazer et al. (128)]. However, further studies are required to determine if the NK cell population expands when IFNT secretion wanes and to what degree, if any, they are involved in placentation.

\section{CONCLUDING REMARIKS}

Intensive cattle production systems have been associated with postpartum immunosuppression and subsequent reduced fertility; it is vital that basic research in the area of bovine reproductive immunology is expanded to generate new knowledge by which these issues can be overcome. However, although the number of studies investigating the contribution of the maternal immune system to reproductive function in cattle is a fraction of that carried out in human and mouse species, it is possible to conclude that maternal macrophage and dendritic cells play pivotal roles in key steps of the establishment of pregnancy, particularly, development of the $\mathrm{CL}$ and maternal immune response to the embryo.

\section{REFERENCES}

1. Diskin MG, Morris DG. Embryonic and early foetal losses in cattle and other ruminants. Reprod Domest Anim (2008) 43(Suppl 2):260-7. doi:10.1111/j. 1439-0531.2008.01171.x

2. Platanias LC. Mechanisms of type-I- and type-II-interferon-mediated signalling. Nat Rev Immunol (2005) 5(5):375-86. doi:10.1038/nri1604

3. Bazer FW. Pregnancy recognition signaling mechanisms in ruminants and pigs. J Anim Sci Biotechnol (2013) 4(1):23. doi:10.1186/2049-1891-4-23

4. Best CL, Pudney J, Welch WR, Burger N, Hill JA. Localization and characterization of white blood cell populations within the human ovary throughout the menstrual cycle and menopause. Hum Reprod (1996) 11(4):790-7. doi:10.1093/oxfordjournals.humrep.a019256

5. Nakamura Y, Smith M, Krishna A, Terranova PF. Increased number of mast cells in the dominant follicle of the cow: relationships among luteal, stromal, and hilar regions. Biol Reprod (1987) 37(3):546-9. doi:10.1095/biolreprod37.3.546

6. Murdoch WJ, Steadman LE. Investigations concerning the relationship of ovarian eosinophilia to ovulation and luteal function in the sheep. Am J Reprod Immunol (1991) 25(2):81-7. doi:10.1111/j.1600-0897.1991.tb01068.x

7. Standaert FE, Zamora CS, Chew BP. Quantitative and qualitative changes in blood leukocytes in the porcine ovary. Am J Reprod Immunol (1991) 25(4):163-8. doi:10.1111/j.1600-0897.1991.tb01088.x

8. Brannstrom M, Enskog A. Leukocyte networks and ovulation. J Reprod Immunol (2002) 57(1-2):47-60. doi:10.1016/S0165-0378(02)00009-8
9. Townson DH, Liptak AR. Chemokines in the corpus luteum: implications of leukocyte chemotaxis. Reprod Biol Endocrinol (2003) 1:94. doi:10.1186/14777827-1-94

10. Harkin DG, Bignold LP, Herriot-Warnes DM, Kirby CA. Chemotaxis of polymorphonuclear leukocytes towards human pre-ovulatory follicular fluid and serum using a 'sparse-pore' polycarbonate filtration membrane. J Reprod Immunol (1994) 27(2):151-5. doi:10.1016/0165-0378(94)90030-2

11. Seow WK, Thong YH, Waters MJ, Walters M, Cummins JM. Isolation of a chemotactic protein for neutrophils from human ovarian follicular fluid. Int Arch Allergy Appl Immunol (1988) 86(3):331-6. doi:10.1159/000234593

12. Sirotkin AV, Luck MR. Potential leukocyte attractants in the bovine periovulatory ovary. Reprod Nutr Dev (1995) 35(6):675-83. doi:10.1051/rnd: 19950607

13. Li Q, Jimenez-Krassel F, Ireland JJ, Smith GW. Gene expression profiling of bovine preovulatory follicles: gonadotropin surge and prostanoid-dependent up-regulation of genes potentially linked to the ovulatory process. Reproduction (2009) 137(2):297-307. doi:10.1530/REP-08-0308

14. Gilbert I, Robert C, Dieleman S, Blondin P, Sirard MA. Transcriptional effect of the LH surge in bovine granulosa cells during the peri-ovulation period. Reproduction (2011) 141(2):193-205. doi:10.1530/REP-10-0381

15. Walsh SW, Fair T, Browne JA, Evans AC, McGettigan PA. Physiological status alters immunological regulation of bovine follicle differentiation in dairy cattle. J Reprod Immunol (2012) 96(1-2):34-44. doi:10.1016/j.jri.2012.07.002

16. Christenson LK, Gunewardena S, Hong X, Spitschak M, Baufeld A, Vanselow J. Research resource: preovulatory LH surge effects on follicular theca and granulosa transcriptomes. Mol Endocrinol (2013) 27(7):1153-71. doi:10.1210/me. 2013-1093

17. Hatzirodos N, Irving-Rodgers HF, Hummitzsch K, Rodgers RJ. Transcriptome profiling of the theca interna from bovine ovarian follicles during atresia. PLoS One (2014) 9(6):e99706. doi:10.1371/journal.pone.0099706

18. Hatzirodos N, Hummitzsch K, Irving-Rodgers HF, Rodgers RJ. Transcriptome profiling of the theca interna in transition from small to large antral ovarian follicles. PLoS One (2014) 9(5):e97489. doi:10.1371/journal.pone.0097489

19. Hatzirodos N, Hummitzsch K, Irving-Rodgers HF, Harland ML, Morris SE, Rodgers RJ. Transcriptome profiling of granulosa cells from bovine ovarian follicles during atresia. BMC Genomics (2014) 15:40. doi:10.1186/1471-216415-40

20. Walsh SW, Mehta JP, McGettigan PA, Browne JA, Forde N, Alibrahim RM, et al. Effect of the metabolic environment at key stages of follicle development in cattle: focus on steroid biosynthesis. Physiol Genomics (2012) 44(9):504-17. doi:10.1152/physiolgenomics.00178.2011

21. Fraser HM. Regulation of the ovarian follicular vasculature. Reprod Biol Endocrinol (2006) 4:18. doi:10.1186/1477-7827-4- 18

22. Turner EC, Mulvaney EP, Reid HM, Kinsella BT. Interaction of the human prostacyclin receptor with the PDZ adapter protein PDZK1: role in endothelial cell migration and angiogenesis. Mol Biol Cell (2011) 22(15):2664-79. doi:10.1091/mbc.E11-04-0374

23. Levitas E, Chamoun D, Udoff LC, Ando M, Resnick CE, Adashi EY. Periovulatory and interleukin-1 beta-dependent up-regulation of intraovarian vascular endothelial growth factor (VEGF) in the rat: potential role for VEGF in the promotion of periovulatory angiogenesis and vascular permeability. J Soc Gynecol Investig (2000) 7(1):51-60. doi:10.1016/S1071-5576(99)00066-0

24. Nilsson MB, Langley RR, Fidler IJ. Interleukin-6, secreted by human ovarian carcinoma cells, is a potent proangiogenic cytokine. Cancer Res (2005) 65(23):10794-800. doi:10.1158/0008-5472.CAN-05-0623

25. Runesson E, Bostrom EK, Janson PO, Brannstrom M. The human preovulatory follicle is a source of the chemotactic cytokine interleukin-8. Mol Hum Reprod (1996) 2(4):245-50. doi:10.1093/molehr/2.4.245

26. Richards JS, Liu Z, Shimada M. Immune-like mechanisms in ovulation. Trends Endocrinol Metab (2008) 19(6):191-6. doi:10.1016/j.tem.2008.03.001

27. Dieleman SJ, Kruip TA, Fontijne P, de Jong WH, van der Weyden GC. Changes in oestradiol, progesterone and testosterone concentrations in follicular fluid and in the micromorphology of preovulatory bovine follicles relative to the peak of luteinizing hormone. J Endocrinol (1983) 97(1):31-42. doi:10.1677/joe.0.0970031

28. Espey LL. Comprehensive analysis of ovarian gene expression during ovulation using differential display. Methods Mol Biol (2006) 317:219-41. doi:10.1385/159259-968-0:219

29. Spanel-Borowski K. Ovulation as danger signaling event of innate immunity. Mol Cell Endocrinol (2011) 333(1):1-7. doi:10.1016/j.mce.2010.12.008 
30. Bianchi ME. DAMPs, PAMPs and alarmins: all we need to know about danger. J Leukoc Biol (2007) 81(1):1-5. doi:10.1189/jlb.0306164

31. Angelucci S, Ciavardelli D, Di Giuseppe F, Eleuterio E, Sulpizio M, Tiboni GM, et al. Proteome analysis of human follicular fluid. Biochim Biophys Acta (2006) 1764(11):1775-85. doi:10.1016/j.bbapap.2006.09.001

32. Tatone C, Amicarelli F, Carbone MC, Monteleone P, Caserta D, Marci R, et al. Cellular and molecular aspects of ovarian follicle ageing. Hum Reprod Update (2008) 14(2):131-42. doi:10.1093/humupd/dmm048

33. Grondahl ML, Borup R, Lee YB, Myrhoj V, Meinertz H, Sorensen S. Differences in gene expression of granulosa cells from women undergoing controlled ovarian hyperstimulation with either recombinant follicle-stimulating hormone or highly purified human menopausal gonadotropin. Fertil Steril (2009) 91(5):1820-30. doi:10.1016/j.fertnstert.2008.02.137

34. Takeda K, Akira S. Toll-like receptors in innate immunity. Int Immunol (2005) 17(1):1-14. doi:10.1093/intimm/dxh186

35. Penny LA, Armstrong D, Bramley TA, Webb R, Collins RA, Watson ED. Immune cells and cytokine production in the bovine corpus luteum throughout the oestrous cycle and after induced luteolysis. J Reprod Fertil (1999) 115(1):87-96. doi:10.1530/jrf.0.1150087

36. Gaytan F, Morales C, Garcia-Pardo L, Reymundo C, Bellido C, Sanchez-Criado JE. Macrophages, cell proliferation, and cell death in the human menstrual corpus luteum. Biol Reprod (1998) 59(2):417-25. doi:10.1095/biolreprod59.2.417

37. Murdoch WJ, McCormick RJ. Mechanisms and physiological implications of leucocyte chemoattraction into periovulatory ovine follicles. J Reprod Fertil (1993) 97(2):375-80. doi:10.1530/jrf.0.0970375

38. Oakley OR, Kim H, El-Amouri I, Lin PC, Cho J, Bani-Ahmad M, et al. Periovulatory leukocyte infiltration in the rat ovary. Endocrinology (2010) 151(9):4551-9. doi:10.1210/en.2009-1444

39. Watanabe H, Tatsumi K, Yokoi H, Higuchi T, Iwai M, Fukuoka M, et al. Ovulation defect and its restoration by bone marrow transplantation in osteopetrotic mutant mice of Mitf(mi)/Mitf(mi) genotype. Biol Reprod (1997) 57(6):1394-400. doi:10.1095/biolreprod57.6.1394

40. Walusimbi SS, Pate JL. Physiology and endocrinology symposium: role of immune cells in the corpus luteum. J Anim Sci (2013) 91(4):1650-9. doi:10. 2527/jas.2012-6179

41. Lobel BL, Levy E. Enzymic correlates of development, secretory function and regression of follicles and corpora lutea in the bovine ovary. Acta Endocrinol (Copenh) (1968) (Suppl 132):5-63.

42. Spanel-Borowski K, Rahner P, Ricken AM. Immunolocalization of CD18positive cells in the bovine ovary. J Reprod Fertil (1997) 111(2):197-205. doi:10.1530/jrf.0.1110197

43. Reynolds LP, Grazul-Bilska AT, Killilea SD, Redmer DA. Mitogenic factors of corpora lutea. Prog Growth Factor Res (1994) 5(2):159-75. doi:10.1016/09552235(94)90003-5

44. Friedman A, Weiss S, Levy N, Meidan R. Role of tumor necrosis factor alpha and its type I receptor in luteal regression: induction of programmed cell death in bovine corpus luteum-derived endothelial cells. Biol Reprod (2000) 63(6):1905-12. doi:10.1095/biolreprod63.6.1905

45. Wang LJ, Brannstrom M, Robertson SA, Norman RJ. Tumor necrosis factor alpha in the human ovary: presence in follicular fluid and effects on cell proliferation and prostaglandin production. Fertil Steril (1992) 58(5):934-40.

46. Okuda K, Sakumoto R. Multiple roles of TNF super family members in corpus luteum function. Reprod Biol Endocrinol (2003) 1:95. doi:10.1186/1477-7827$1-95$

47. Galvao A, Henriques S, Pestka D, Lukasik K, Skarzynski D, Mateus LM, et al. Equine luteal function regulation may depend on the interaction between cytokines and vascular endothelial growth factor: an in vitro study. Biol Reprod (2012) 86(6):187. doi:10.1095/biolreprod.111.097147

48. O'Leary S, Jasper MJ, Robertson SA, Armstrong DT. Seminal plasma regulates ovarian progesterone production, leukocyte recruitment and follicular cell responses in the pig. Reproduction (2006) 132(1):147-58. doi:10.1530/rep. 1.01119

49. O’Leary S, Jasper MJ, Warnes GM, Armstrong DT, Robertson SA. Seminal plasma regulates endometrial cytokine expression, leukocyte recruitment and embryo development in the pig. Reproduction (2004) 128(2):237-47. doi:10.1530/rep.1.00160

50. Bauer M, Reibiger I, Spanel-Borowski K. Leucocyte proliferation in the bovine corpus luteum. Reproduction (2001) 121(2):297-305. doi:10.1530/rep. 0.1210297
51. Poole DH, Pate JL. Luteal microenvironment directs resident T lymphocyte function in cows. Biol Reprod (2012) 86(2):29. doi:10.1095/biolreprod.111. 092296

52. Cannon MJ, Petroff MG, Pate JL. Effects of prostaglandin F2alpha and progesterone on the ability of bovine luteal cells to stimulate $\mathrm{T}$ lymphocyte proliferation. Biol Reprod (2003) 69(2):695-700. doi:10.1095/biolreprod.103. 017590

53. Neuvians TP, Schams D, Berisha B, Pfaffl MW. Involvement of proinflammatory cytokines, mediators of inflammation, and basic fibroblast growth factor in prostaglandin F2alpha-induced luteolysis in bovine corpus luteum. Biol Reprod (2004) 70(2):473-80. doi:10.1095/biolreprod.103.016154

54. Hehnke KE, Christenson LK, Ford SP, Taylor M. Macrophage infiltration into the porcine corpus luteum during prostaglandin F2 alpha-induced luteolysis. Biol Reprod (1994) 50(1):10-5. doi:10.1095/biolreprod50.1.10

55. Shaw DW, Britt JH. Concentrations of tumor necrosis factor alpha and progesterone within the bovine corpus luteum sampled by continuous-flow microdialysis during luteolysis in vivo. Biol Reprod (1995) 53(4):847-54. doi:10.1095/biolreprod53.4.847

56. Galvao A, Skarzynski DJ, Szostek A, Silva E, Tramontano A, Mollo A, et al. Cytokines tumor necrosis factor-alpha and interferon-gamma participate in modulation of the equine corpus luteum as autocrine and paracrine factors. J Reprod Immunol (2012) 93(1):28-37. doi:10.1016/j.jri.2011.11.002

57. Sakumoto R, Vermehren M, Kenngott RA, Okuda K, Sinowatz F. Localization of gene and protein expressions of tumor necrosis factor-\{alpha\} and tumor necrosis factor receptor types I and II in the bovine corpus luteum during the estrous cycle. J Anim Sci (2011) 89(10):3040-7. doi:10.2527/jas.2010-3479

58. Porter DA, Vickers SL, Cowan RG, Huber SC, Quirk SM. Expression and function of Fas antigen vary in bovine granulosa and theca cells during ovarian follicular development and atresia. Biol Reprod (2000) 62(1):62-6. doi:10.1095/biolreprod62.1.62

59. Suarez SS, Pacey AA. Sperm transport in the female reproductive tract. Hum Reprod Update (2006) 12(1):23-37. doi:10.1093/humupd/dmi047

60. Tyler KR. Histological changes in the cervix of the rabbit after coitus. J Reprod Fertil (1977) 49(2):341-5. doi:10.1530/jrf.0.0490341

61. Pandya IJ, Cohen J. The leukocytic reaction of the human uterine cervix to spermatozoa. Fertil Steril (1985) 43(3):417-21.

62. Robertson SA. Seminal plasma and male factor signalling in the female reproductive tract. Cell Tissue Res (2005) 322(1):43-52. doi:10.1007/s00441-0051127-3

63. Tomlinson MJ, White A, Barratt CL, Bolton AE, Cooke ID. The removal of morphologically abnormal sperm forms by phagocytes: a positive role for seminal leukocytes? Hum Reprod (1992) 7(4):517-22.

64. Troedsson MH, Liu IK, Crabo BG. Sperm transport and survival in the mare. Theriogenology (1998) 49(5):905-15. doi:10.1016/S0093-691X(98)00040-5

65. Mattner PE. The distribution of spermatozoa and leucocytes in the female genital tract in goats and cattle. J Reprod Fertil (1968) 17(2):253-61. doi:10.1530/ jrf.0.0170253

66. Robertson SA, Mau VJ, Tremellen KP, Seamark RF. Role of high molecular weight seminal vesicle proteins in eliciting the uterine inflammatory response to semen in mice. J Reprod Fertil (1996) 107(2):265-77. doi:10.1530/jrf.0. 1070265

67. Sharkey DJ, Macpherson AM, Tremellen KP, Mottershead DG, Gilchrist RB, Robertson SA. TGF-beta mediates proinflammatory seminal fluid signaling in human cervical epithelial cells. J Immunol (2012) 189(2):1024-35. doi:10.4049/jimmunol.1200005

68. Rubtsov YP, Rudensky AY. TGFbeta signalling in control of T-cell-mediated self-reactivity. Nat Rev Immunol (2007) 7(6):443-53. doi:10.1038/nri2095

69. Tremellen KP, Seamark RF, Robertson SA. Seminal transforming growth factor betal stimulates granulocyte-macrophage colony-stimulating factor production and inflammatory cell recruitment in the murine uterus. Biol Reprod (1998) 58(5):1217-25. doi:10.1095/biolreprod58.5.1217

70. Moldenhauer LM, Diener KR, Thring DM, Brown MP, Hayball JD, Robertson SA. Cross-presentation of male seminal fluid antigens elicits $\mathrm{T}$ cell activation to initiate the female immune response to pregnancy. J Immunol (2009) 182(12):8080-93. doi:10.4049/jimmunol.0804018

71. Bennouna S, Bliss SK, Curiel TJ, Denkers EY. Cross-talk in the innate immune system: neutrophils instruct recruitment and activation of dendritic cells during microbial infection. J Immunol (2003) 171(11):6052-8. doi:10.4049/jimmunol.171.11.6052 
72. Chertov O, Ueda H, Xu LL, Tani K, Murphy WJ, Wang JM, et al. Identification of human neutrophil-derived cathepsin G and azurocidin/CAP37 as chemoattractants for mononuclear cells and neutrophils. J Exp Med (1997) 186(5):739-47. doi:10.1084/jem.186.5.739

73. Waberski D, Dohring A, Ardon F, Ritter N, Zerbe H, Schuberth HJ, et al. Physiological routes from intra-uterine seminal contents to advancement of ovulation. Acta Vet Scand (2006) 48:13. doi:10.1186/1751-0147-48-S1-S13

74. Robertson SA. Seminal fluid signaling in the female reproductive tract: lessons from rodents and pigs. J Anim Sci (2007) 85(13 Suppl):E36-44. doi:10.2527/jas.2006-578

75. Robertson SA, O'Connell AC, Hudson SN, Seamark RF. Granulocytemacrophage colony-stimulating factor (GM-CSF) targets myeloid leukocytes in the uterus during the post-mating inflammatory response in mice. J Reprod Immunol (2000) 46(2):131-54. doi:10.1016/S0165-0378(99)00060- 1

76. Schuberth HJ, Taylor U, Zerbe H, Waberski D, Hunter R, Rath D. Immunological responses to semen in the female genital tract. Theriogenology (2008) 70(8):1174-81. doi:10.1016/j.theriogenology.2008.07.020

77. Gutsche S, von Wolff M, Strowitzki T, Thaler CJ. Seminal plasma induces mRNA expression of IL-1beta, IL-6 and LIF in endometrial epithelial cells in vitro. Mol Hum Reprod (2003) 9(12):785-91. doi:10.1093/molehr/gag095

78. Mansouri-Attia N, Oliveira LJ, Forde N, Fahey AG, Browne JA, Roche JF, et al. Pivotal role for monocytes/macrophages and dendritic cells in maternal immune response to the developing embryo in cattle. Biol Reprod (2012) 87(5):123. doi:10.1095/biolreprod.112.101121

79. Odhiambo JF, Poole DH, Hughes L, Dejarnette JM, Inskeep EK, Dailey RA. Pregnancy outcome in dairy and beef cattle after artificial insemination and treatment with seminal plasma or transforming growth factor beta-1. Theriogenology (2009) 72(4):566-71. doi:10.1016/j.theriogenology.2009.04.013

80. Lima FS, Risco CA, Thatcher MJ, Benzaquen ME, Archbald LF, Santos JE, et al. Comparison of reproductive performance in lactating dairy cows bred by natural service or timed artificial insemination. J Dairy Sci (2009) 92(11):5456-66. doi:10.3168/jds.2009-2197

81. Robertson SA, Guerin LR, Moldenhauer LM, Hayball JD. Activating T regulatory cells for tolerance in early pregnancy - the contribution of seminal fluid. J Reprod Immunol (2009) 83(1-2):109-16. doi:10.1016/j.jri.2009.08.003

82. Spencer TE, Johnson GA, Bazer FW, Burghardt RC, Palmarini M. Pregnancy recognition and conceptus implantation in domestic ruminants: roles of progesterone, interferons and endogenous retroviruses. Reprod Fertil Dev (2007) 19(1):65-78. doi:10.1071/RD06102

83. Wegmann TG. Maternal T cells promote placental growth and prevent spontaneous abortion. Immunol Lett (1988) 17(4):297-302. doi:10.1016/01652478(88)90001-6

84. Raghupathy R. Th1-type immunity is incompatible with successful pregnancy. Immunol Today (1997) 18(10):478-82. doi:10.1016/S0167-5699(97)01127-4

85. Lin H, Mosmann TR, Guilbert L, Tuntipopipat S, Wegmann TG. Synthesis of T helper 2-type cytokines at the maternal-fetal interface. J Immunol (1993) 151(9):4562-73.

86. Chaouat G. The Th1/Th2 paradigm: still important in pregnancy? Semin Immunopathol (2007) 29(2):95-113. doi:10.1007/s00281-007-0069-0

87. Bazer FW, Spencer TE, Ott TL. Interferon tau: a novel pregnancy recognition signal. Am J Reprod Immunol (1997) 37(6):412-20. doi:10.1111/j.1600-0897. 1997.tb00253.x

88. Martal JL, Chene NM, Huynh LP, L'Haridon RM, Reinaud PB, Guillomot MW, et al. IFN-tau: a novel subtype I IFN1. Structural characteristics, nonubiquitous expression, structure-function relationships, a pregnancy hormonal embryonic signal and cross-species therapeutic potentialities. Biochimie (1998) 80(8-9):755-77. doi:10.1016/S0300-9084(99)80029-7

89. Godkin JD, Bazer FW, Thatcher WW, Roberts RM. Proteins released by cultured day 15-16 conceptuses prolong luteal maintenance when introduced into the uterine lumen of cyclic ewes. J Reprod Fertil (1984) 71(1):57-64. doi:10.1530/jrf.0.0710057

90. Spencer TE, Becker WC, George P, Mirando MA, Ogle TF, Bazer FW. Ovine interferon-tau regulates expression of endometrial receptors for estrogen and oxytocin but not progesterone. Biol Reprod (1995) 53(3):732-45. doi:10.1095/ biolreprod53.3.732

91. Ott TL, Fleming JG, Spencer TE, Joyce MM, Chen P, Green CN, et al. Effects of exogenous recombinant ovine interferon tau on circulating concentrations of progesterone, cortisol, luteinizing hormone, and antiviral activity; interestrous interval; rectal temperature; and uterine response to oxytocin in cyclic ewes. Biol Reprod (1997) 57(3):621-9. doi:10.1095/biolreprod57.3.621

92. Choi Y, Johnson GA, Spencer TE, Bazer FW. Pregnancy and interferon tau regulate major histocompatibility complex class I and beta2-microglobulin expression in the ovine uterus. Biol Reprod (2003) 68(5):1703-10. doi:10.1095/ biolreprod.102.012708

93. Hansen TR, Austin KJ, Johnson GA. Transient ubiquitin cross-reactive protein gene expression in the bovine endometrium. Endocrinology (1997) 138(11):5079-82. doi:10.1210/endo.138.11.5655

94. Johnson GA, Austin KJ, Collins AM, Murdoch WJ, Hansen TR. Endometrial ISG17 mRNA and a related mRNA are induced by interferon-tau and localized to glandular epithelial and stromal cells from pregnant cows. Endocrine (1999) 10(3):243-52. doi:10.1007/BF02738623

95. Song G, Bazer FW, Spencer TE. Pregnancy and interferon tau regulate RSAD2 and IFIH1 expression in the ovine uterus. Reproduction (2007) 133(1):285-95. doi:10.1530/REP-06-0092

96. Hansen TR, Imakawa K, Polites HG, Marotti KR, Anthony RV, Roberts RM. Interferon RNA of embryonic origin is expressed transiently during early pregnancy in the ewe. J Biol Chem (1988) 263(26):12801-4.

97. Doyle J, Ellis SA, O’Gorman GM, Aparicio Donoso IM, Lonergan P, Fair T. Classical and non-classical major histocompatibility complex class I gene expression in in vitro derived bovine embryos. J Reprod Immunol (2009) 82(1):48-56 doi:10.1016/j.jri.2009.06.125

98. Bainbridge DR, Sargent IL, Ellis SA. Increased expression of major histocompatibility complex (MHC) class I transplantation antigens in bovine trophoblast cells before fusion with maternal cells. Reproduction (2001) 122(6):907-13. doi:10.1530/rep.0.1220907

99. O’Gorman GM, Al Naib A, Ellis SA, Mamo S, O’Doherty AM, Lonergan P, et al. Regulation of a bovine nonclassical major histocompatibility complex class I gene promoter. Biol Reprod (2010) 83(2):296-306. doi:10.1095/biolreprod. 109.082560

100. Al Naib A, Mamo S, O’Gorman GM, Lonergan P, Swales A, Fair T. Regulation of non-classical major histocompatability complex class I mRNA expression in bovine embryos. J Reprod Immunol (2011) 91(1-2):31-40. doi:10.1016/j.jri.2011.05.005

101. Fest S, Aldo PB, Abrahams VM, Visintin I, Alvero A, Chen R, et al. Trophoblastmacrophage interactions: a regulatory network for the protection of pregnancy. Am J Reprod Immunol (2007) 57(1):55-66. doi:10.1111/j.1600-0897. 2006.00446.x

102. Mincheva-Nilsson L, Baranov V, Yeung MM, Hammarstrom S, Hammarstrom ML. Immunomorphologic studies of human decidua-associated lymphoid cells in normal early pregnancy. J Immunol (1994) 152(4):2020-32.

103. McIntire RH, Ganacias KG, Hunt JS. Programming of human monocytes by the uteroplacental environment. Reprod Sci (2008) 15(5):437-47. doi:10.1177/ 1933719107314065

104. Dambaeva SV, Breburda EE, Durning M, Garthwaite MA, Golos TG. Characterization of decidual leukocyte populations in cynomolgus and vervet monkeys. J Reprod Immunol (2009) 80(1-2):57-69. doi:10.1016/j.jri.2008.12.006

105. Tekin S, Hansen PJ. Regulation of numbers of macrophages in the endometrium of the sheep by systemic effects of pregnancy, local presence of the conceptus, and progesterone. Am J Reprod Immunol (2004) 51(1):56-62. doi:10.1046/j.8755-8920.2003.00125.x

106. Oliveira LJ, McClellan S, Hansen PJ. Differentiation of the endometrial macrophage during pregnancy in the cow. PLoS One (2010) 5(10):e13213. doi:10.1371/journal.pone.0013213

107. Oliveira LJ, Hansen PJ. Phenotypic characterization of macrophages in the endometrium of the pregnant cow. Am J Reprod Immunol (2009) 62(6):418-26. doi:10.1111/j.1600-0897.2009.00761.x

108. Straszewski-Chavez SL, Abrahams VM, Mor G. The role of apoptosis in the regulation of trophoblast survival and differentiation during pregnancy. Endocr $\operatorname{Rev}(2005)$ 26(7):877-97. doi:10.1210/er.2005-0003

109. Kzhyshkowska J, Gratchev A, Schmuttermaier C, Brundiers H, Krusell L, Mamidi S, et al. Alternatively activated macrophages regulate extracellular levels of the hormone placental lactogen via receptor-mediated uptake and transcytosis. J Immunol (2008) 180(5):3028-37. doi:10.4049/jimmunol.180.5.3028

110. Plaks V, Birnberg T, Berkutzki T, Sela S, BenYashar A, Kalchenko V, et al. Uterine DCs are crucial for decidua formation during embryo implantation in mice. J Clin Invest (2008) 118(12):3954-65. doi:10.1172/JCI36682 
111. Blois SM, Kammerer U, Alba Soto C, Tometten MC, Shaikly V, Barrientos G, et al. Dendritic cells: key to fetal tolerance? Biol Reprod (2007) 77(4):590-8. doi:10.1095/biolreprod.107.060632

112. Dietl J, Honig A, Kammerer U, Rieger L. Natural killer cells and dendritic cells at the human feto-maternal interface: an effective cooperation? Placenta (2006) 27(4-5):341-7. doi:10.1016/j.placenta.2005.05.001

113. Tirado-Gonzalez I, Munoz-Fernandez R, Blanco O, Leno-Duran E, AbadiaMolina AC, Olivares EG. Reduced proportion of decidual DC-SIGN+ cells in human spontaneous abortion. Placenta (2010) 31(11):1019-22. doi:10.1016/j. placenta.2010.09.008

114. Gu L, Rutledge B, Fiorillo J, Ernst C, Grewal I, Flavell R, et al. In vivo properties of monocyte chemoattractant protein-1. J Leukoc Biol (1997) 62(5):577-80.

115. Salustri A, Garlanda C, Hirsch E, De Acetis M, Maccagno A, Bottazzi B, et al. PTX3 plays a key role in the organization of the cumulus oophorus extracellular matrix and in in vivo fertilization. Development (2004) 131(7):1577-86. doi:10.1242/dev.01056

116. Rovere P, Peri G, Fazzini F, Bottazzi B, Doni A, Bondanza A, et al. The long pentraxin PTX3 binds to apoptotic cells and regulates their clearance by antigenpresenting dendritic cells. Blood (2000) 96(13):4300-6.

117. Garlanda C, Hirsch E, Bozza S, Salustri A, De Acetis M, Nota R, et al. Non-redundant role of the long pentraxin PTX3 in anti-fungal innate immune response. Nature (2002) 420(6912):182-6. doi:10.1038/ nature01195

118. Deban L, Russo RC, Sironi M, Moalli F, Scanziani M, Zambelli V, et al. Regulation of leukocyte recruitment by the long pentraxin PTX3. Nat Immunol (2010) 11(4):328-34. doi:10.1038/ni.1854

119. Oliveira LJ, Mansourri-Attia N, Fahey AG, Browne J, Forde N, Roche JF, et al. Characterization of the Th profile of the bovine endometrium during the oestrous cycle and early pregnancy. PLoS One (2013) 8(10):e75571. doi:10.1371/journal.pone.0075571

120. Conti P, Reale M, Barbacane RC, Bongrazio M, Panara MR, Fiore S, et al. Leukocyte inhibitory factor activates human neutrophils and macrophages to release leukotriene B4 and thromboxanes. Cytokine (1990) 2(2):142-8. doi:10.1016/1043-4666(90)90008-H

121. Svensson J, Jenmalm MC, Matussek A, Geffers R, Berg G, Ernerudh J. Macrophages at the fetal-maternal interface express markers of alternative activation and are induced by M-CSF and IL-10. J Immunol (2011) 187(7):3671-82. doi:10.4049/jimmunol.1100130
122. Munson L, Wilhite A, Boltz VF, Wilkinson JE. Transforming growth factor beta in bovine placentas. Biol Reprod (1996) 55(4):748-55. doi:10.1095/ biolreprod55.4.748

123. Wahl SM, Hunt DA, Wakefield LM, McCartney-Francis N, Wahl LM, Roberts $\mathrm{AB}$, et al. Transforming growth factor type beta induces monocyte chemotaxis and growth factor production. Proc Natl Acad Sci US A (1987) 84(16):5788-92. doi:10.1073/pnas.84.16.5788

124. Graham CH, Lala PK. Mechanism of control of trophoblast invasion in situ. J Cell Physiol (1991) 148(2):228-34. doi:10.1002/jcp.1041480207

125. Munoz-Suano A, Hamilton AB, Betz AG. Gimme shelter: the immune system during pregnancy. Immunol Rev (2011) 241 (1):20-38. doi:10.1111/j.1600065X.2011.01002.X

126. Mor G, Cardenas I, Abrahams V, Guller S. Inflammation and pregnancy: the role of the immune system at the implantation site. Ann N Y Acad Sci (2011) 1221:80-7. doi:10.1111/j.1749-6632.2010.05938.x

127. Skopets B, Li J, Thatcher WW, Roberts RM, Hansen PJ. Inhibition of lymphocyte proliferation by bovine trophoblast protein-1 (type I trophoblast interferon) and bovine interferon-alpha I1. Vet Immunol Immunopathol (1992) 34(1-2):81-96. doi:10.1016/0165-2427(92)90153-H

128. Bazer FW, Spencer TE, Johnson GA, Burghardt RC, Wu G. Comparative aspects of implantation. Reproduction (2009) 138(2):195-209. doi:10.1530/REP-090158

Conflict of Interest Statement: The author declares that the research was conducted in the absence of any commercial or financial relationships that could be construed as a potential conflict of interest.

Received: 16 October 2014; paper pending published: 15 November 2014; accepted: 07 January 2015; published online: 28 January 2015.

Citation: Fair T (2015) The contribution of the maternal immune system to the establishment of pregnancy in cattle. Front. Immunol. 6:7. doi: 10.3389/fimmu.2015.00007 This article was submitted to Molecular Innate Immunity, a section of the journal Frontiers in Immunology.

Copyright (c) 2015 Fair. This is an open-access article distributed under the terms of the Creative Commons Attribution License (CC BY). The use, distribution or reproduction in other forums is permitted, provided the original author(s) or licensor are credited and that the original publication in this journal is cited, in accordance with accepted academic practice. No use, distribution or reproduction is permitted which does not comply with these terms. 